Aleksander Wojciech Mikołajczak

\title{
Ad rem, czyli ku nowej recepcji antyku w ponowoczesnym świecie
}

\begin{abstract}
Mikołajczak Aleksander Wojciech, Ad rem, czyli ku nowej recepcji antyku w ponowoczesnym świecie [Ad rem, towards a new reception of antiquity in the post-modern World]. „Przestrzenie Teorii" 30. Poznań 2018, Adam Mickiewicz University Press, pp. 113-131. ISSN 1644-6763. DOI 10.14746/pt.2018.30.5.
\end{abstract}

This article presents the shift in the ontological status and function of Ancient Greek and Roman cultural heritage undergone by Western civilization in the last decades of the twentieth and early twenty-first centuries. Antique tradition has since ceased to be transmitted simply as a system of ideas, values or role models, which was successively actualized in the process of its reception. In the post-modern consciousness, Ancient Greek and Roman heritage began to be understood as an individual collection of objects, consumed by society and adapted for the implementation of specific aims and aspirations. This shift consequentially results in the obsolescence of the investigative methodologies used in the study of the reception of antiquity, which have been adapted so far, and thus challenges us to search for more adequate ways of description and analysis of this cultural phenomenon. In light of this, the article presents a new understanding of the reception process and postulates a new research method, referring to the categories of speculative realism, theory of metadesign and the concept of Actor Network Theory (ANT).

KEYWORDS: classical or antique heritage, postmodernity, objects, methodology, speculative realism, metadesign, Actor Network Theory (ANT)

Jeszcze nigdy dziedzictwo antycznej Grecji i Rzymu w swej namacalnej postaci nie było bliżej nas niż dzisiaj, a jednocześnie w swych kulturowych znaczeniach oraz funkcjach bardziej się od nas nie oddaliło niż obecnie. Wystarczy przejść się ulicami którejś z zachodnich metropolii, by z łatwością napotkać motywy antyczne wykorzystane na reklamowych bilbordach, w logotypach i nazwach firm, aranżacjach sklepowych witryn, detalach architektonicznych - a nawet rozpoznać je umieszczone na T-shirtach mijanych przechodniów ${ }^{1}$. Bez większego trudu prawie każdy może na własne oczy podziwiać w Luwrze posag Nike z Samotraki, osobiście znaleźć się na ateńskim Akropolu albo przespacerować po Forum Romanum - wystarczy wykupić bilet lotniczy, by za kilka godzin być w jednym z tych antycznych miejsc. Jeszcze łatwiej odnaleźć greckie i rzymskie dziedzictwo na portalach

${ }^{1}$ Tematowi recepcji antyku w popkulturze poświęcona była międzynarodowa konferencja: Antiquity in Popular Literature and Culture, zorganizowana w 2014 roku na Uniwersytecie im. Adama Mickiewicza w Poznaniu, <www.phsi.amu.edu.pl/fancud_konferencja. html> [dostęp: 14.04.2015]. 
i stronach internetowych - kliknięciem uzyskując natychmiastowy dostęp do korpusu starożytnych tekstów ${ }^{2}$ albo do filmoteki dzieł światowej kinematografii odnoszących się do klasycznej starożytności ${ }^{3}$. Paradoks polega jednak na tym, że chociaż antyczne treści w swej różnorakiej obecności dostępne są dziś dosłownie na wyciagnięcie ręki, to dla przeciętnego Europejczyka stają się one coraz mniej oczywiste jako żywy przekaz kulturowy, wciąż kształtujący współczesną tożsamość Zachodu. W kontekście światowej sytuacji wywoływanej zjawiskiem określanym dzisiaj jako „zderzenie cywilizacji” "4akie obluzowanie jednego z kamieni węgielnych europejskiej samoświadomości skłaniać musi do refleksji.

Celem niniejszych rozważań będzie zatem próba przyjrzenia się nowym fenomenom uobecniania się dziedzictwa antycznego w ponowoczesnym świecie, które głęboko odmieniły sposób jego postrzegania, znacząco redefiniując tradycyjnie przypisywane greckim i rzymskim motywom sensy, a co za tym idzie, także kulturowe funkcje. Wymaga to świeżego namysłu nad czynnikami warunkującymi ów proces, wśród których najważniejszymi wydają się: gwałtowny rozwój technologii, metod masowej produkcji i cyfrowego przetwarzania informacji, ściśle powiązanych z ukształtowaniem się społeczeństwa zdominowanego przez konsumpcję i poddawanego presji popkulturowej manipulacji. Zjawiska te wpływają na ukształtowanie się nowych mechanizmów replikacji i referencji antycznego dziedzictwa w naszym świecie, skłaniajac do zrewidowania dotychczasowych metodologii badań nad jego recepcja w zachodniej cywilizacji. Próbą zaproponowania świeżego podejścia do tych dociekań staną się więc rozważania nad nowymi kategoriami poznawczymi, które moga okazać się w tym zakresie inspirujące, badawczo przydatne i intelektualnie płodne.

\section{Zwrot ku rzeczom}

Można zaryzykować twierdzenie, że w wyniku wspomnianych zmian cywilizacyjnych doszło do stopniowego zacierania się i rozmywania grecko-rzymskiego kodu kulturowego. Przestał być on skutecznie aktualizowany $\mathrm{w}$ procesie intencjonalnej recepcji, a także w systemie formalnej edukacji,

${ }^{2}$ Zob. np. portal Tufts University: Perseus Digital Library, <www.perseus.tufts.edu> [dostęp: 14.04.2015].

${ }^{3}$ Zob. np. portal: Best Films about Ancient and Medieval Times, <www.imdb.com/list/ ls008306192/> [dostęp: 16.04.2015].

${ }^{4}$ Termin ten zaproponował Samuel P. Huntington w wydanej w 1996 r. książce: The Clash of Civilizations and the Remaking of World Order (wyd. polskie: Zderzenie cywilizacji i nowy ksztatt tadu światowego, przeł. H. Jankowska, Warszawa 1997). 
ukierunkowanych już to na komercję, już to na praktyczny utylitaryzm. W świadomości społecznej wpłynęło to na zmianę i deformację artykułowanych za pomoca tego kodu treści, które, stopniowo gubiąc pierwotne, archetypiczne sensy, stały się z czasem czymś w rodzaju kulturowych wydmuszek. W rezultacie ich nieostre, uproszczone pojmowanie niejednokrotnie ogranicza się dzisiaj do imputowanych przez kulturę popularna stereotypowych skojarzeń, w których motywy antyczne wykorzystuje się najczęściej do powierzchownego uatrakcyjniania marketingowych przekazów ${ }^{5}$. W konsumpcyjnym społeczeństwie prowadzi to do swoistego, funkcjonalnego uprzedmiotowienia greckiego i rzymskiego dziedzictwa, co - wobec powszechnej skali tych zjawisk - powoduje zasadnicze zmiany w sposobie uobecniania się i artykulacji antyku w kulturze ponowoczesnej.

Procesy te należy rozpatrywać w kontekście szerszych przemian, do jakich w ostatnich dekadach XX i na początku XXI wieku doszło w zachodnim świecie, gdzie jeszcze nigdy w historii tak wielu z nas nie miało aż tak wielu przedmiotów. Ich posiadanie stało się wyrazem spełnienia marzeń, miarą odnoszenia życiowych sukcesów, zdobywania społecznego uznania, a wreszcie gwarancją bezpieczeństwa i w ogóle synonimem szczęścia $^{6}$. Dzisiejszy świat, wypełniony po brzegi przedmiotami, nieledwie duszacy się od ich nadmiaru, zdaje się zatracać świadomość istnienia czegokolwiek innego prócz nich, stając się przestrzenia, gdzie również motywy antyczne zaczynaja być postrzegane bardziej jako rzeczy niż kulturowe wartości lub znaczące wzorce. Prowadzi to do ustanawiania ich nowej, uprzedmiotowionej obecności, co radykalnie odmienia status ontologiczny greckiego i rzymskiego dziedzictwa, a co za tym idzie, redefiniuje także jego tradycyjne funkcje. Sytuacja taka powoduje, że chcąc zrozumieć istotę owych zjawisk, trzeba koniecznie podjąć refleksję nad natura samych przedmiotów oraz nad rola, jaka odgrywaja one w interakcjach z użytkownikami. Potrzebę pilnego uwzględnienia tej nowej perspektywy sugeruje dokonujący się ostatnimi czasy w naukach społecznych i humanistycznych metodologiczny zwrot ku materialności, którego promotorami sa dzisiaj tacy filozofowie jak Graham Harman, Bruno Latour oraz Quentin Meillassoux?

${ }^{5}$ Zob. analizę marketingu firmy Asus w kontekście mitu o Pegazie: K. Dominas, Internetowa recepcja mitu na przykładzie wybranych podań grecko-rzymskiej literatury, [w:] Studia mitoznawcze. Wspótczesna obecność mitu, red. I. Błocian, E. Kwiatkowska, Toruń 2012, s. $135-157$.

${ }^{6}$ Zob. D. Sudjic, Język rzeczy. Dizajn i luksus, moda i sztuka. W jaki sposób przedmioty nas uwodza, przeł. A. Puchejda, Kraków 2013, s. 5-11.

${ }^{7}$ Więcej na temat zwrotu ku materialności zob. w numerze tematycznym „Kronos” (Realizm spekulatywny. Przygodność, wirtualność, konieczność) 2012, nr 1. 
Nie ulega wątpliwości, że to nowe podejście wydaje się wskazane i adekwatne także w stosunku do zrozumienia nowej roli antyku we współczesnej kulturze. Jego uprzedmiotowienie jest bowiem wynikiem oraz zarazem przejawem widocznych mutacji cywilizacyjnego paradygmatu i swoistym signum temporis ponowoczesności. Jednym z nieuniknionych tego skutków stała się erozja antropocentryzmu w postrzeganiu świata, który w swojej fenomenologicznej podstawie wydaje się coraz bardziej zreifikowany, a przez to coraz mniej ludzki. Prowadzi to w konsekwencji do kryzysu ludzkiej podmiotowości, albowiem przedmioty, bez których współczesna cywilizacja nie może się obejść, w coraz większym stopniu przejmują kontrolę nad naszym życiem. W rezultacie przewartościowaniu ulegają dotychczasowe relacje między tym, co postrzegaliśmy jako duchowe, czyli podmiotowe, i tym, co uznajemy za materialne, czyli przedmiotowe, kierując naszą uwagę i refleksję raczej ku materialnemu światu, niż ku sposobom jego uobecniania się w naszych umysłach.

Zarysowana w ten sposób kontekstualna perspektywa skłania zatem do zaakceptowania (postulowanego przez zwrot ku przedmiotom) rzeczowego traktowania motywów antycznych, niezależnie od ich statusu ontologicznego, czyli sposobu uobecniania się w ludzkim świecie. Jeśli przyjąć założenia realizmu spekulatywnego Grahama Harmana, całe grecko-rzymskie dziedzictwo uznać można właściwie za specyficzny zbiór rzeczy (obiektów). Chociaż każda z nich ma wiele różnych atrybutywnych cech i pełni wiele rozmaitych funkcji, stanowi przecież wyodrębnianą i uchwytną sensualnie oraz spekulatywnie całość. Dotyczy to zatem nie tylko obiektów materialnych, lecz także przedmiotów metafizycznych, takich jak inwokacja do Odysei czy akt zabicia Minotaura. Jak pisze bowiem Harman:

Otwierając mój egzemplarz Dziejów Rzymu Gibbona, czytam o historycznych przedmiotach, których nie ma już w naszym świecie - na przykład o Dioklecjanie i o gnostykach. Matematycy, którzy porzucają świat fizyczny i zagłębiają się w sferze idealnej, mają do czynienia z przedmiotami takimi jak liczby całkowite i stożki. To samo dotyczy centaurów, Pegaza i jednorożca $[\ldots]^{8}$.

\section{Wokół przedmiotu poczwórnego}

Tak radykalnie rzeczowe postrzeganie grecko-rzymskiego dziedzictwa rodzi jednak pytanie o istotowa naturę przedmiotowo ujmowanych i rozumianych motywów antycznych, które istnieją przecież w rozmaity sposób i manifestują się w różnych materialnych oraz abstrakcyjnych wymiarach

\footnotetext{
${ }^{8}$ G. Harman, Traktat o przedmiotach, przekł. i posłowie M. Rychter, Warszawa 2013,
} s. 20 . 
bytu. Pytanie to w innym sensie ma również charakter epistemologiczny, albowiem dotyka kwestii odmiennej percepcji rzeczowego i wyobrażeniowego uobecnienia się antycznych przedmiotów. Czymś innym jest przecież zmysłowe obcowanie z wizerunkiem Cezara wybitym na denarze, a czymś innym pojęciowe przywoływanie wydarzeń Idów marcowych na drodze umysłowej spekulacji. Problem ontologii rzeczy musiał się więc znaleźć w centrum Harmanowskiej teorii tak zwanego przedmiotu poczwórnego, gdzie zyskał błyskotliwe rozwiązanie w postaci relacyjnego rozumienia ontologii rzeczy.

Zwięzłe objaśnienie tej koncepcji odnajdujemy w przedmowie do polskiego wydania Traktatu o przedmiotach Harmana, która wyszła spod pióra Szymona Wróbla, tak oto charakteryzującego przedmiot poczwórny:

[...] ma on cztery bieguny, którymi są: przedmioty rzeczywiste, własności rzeczywiste, przedmioty zmysłowe i własności zmysłowe. Jeśli dobrze rozumiem to rozróżnienie, rzeczywisty kot-przedmiot ma rzeczywiste własności (np. szybkość poruszania się, umiejętności łowieckie itp.). Zmysłowy kot-przedmiot to jednak kot, którego widzę, gdy bezszelestnie czai się w trawie. Własności zmysłowe są odmienne dla mnie jako człowieka (słodki zwierzak) i myszy próbującej się przed tym przedmiotem ukryć (straszny zwierzak). Własności zmysłowe doświadczane przez mysz zostały wycofane z mojego rejestru doznań zmysłowych, tj. z mojego pola fenomenologicznego. Nie oznacza to jednak, że są one nierealne, to właśnie ich realność nakazuje myszy uruchomienie scenariusza ucieczki ${ }^{9}$.

Z tej obrazowej charakterystyki konceptu Harmana jasno wynika, że złożona ontologia rzeczy może stanowić rodzaj wspólnego mianownika dla przedmiotowo kategoryzowanych greckich i rzymskich motywów. Niezależnie bowiem od sposobu ich uobecniania się - a co za tym idzie percepcyjnej poznawalności - stanowią one nie tylko obiekty naszego postrzegania i umysłowej spekulacji, lecz także umożliwiają wchodzenie z nimi w interakcje. W Harmanowskiej perspektywie przedmioty antyczne, chociaż nie ujawniaja swej pojęciowej natury (niczym przywołany przez Wróbla kot), to przecież uobecniane w zmysłowej postaci, pozwalają wnioskować o niedostępnych poznaniu istotowych atrybutach danej rzeczy (to znaczy przedmiotu rzeczywistego). Z namacalnego fragmentu etruskiej amfory możemy wyobrażeniowo odtworzyć jej ukryty, wysmukły kształt, by zawrzeć go następnie w formie na przykład wiecznego pióra, jak stało się to w modelem Etruria włoskiej marki Stipula ${ }^{10}$. W podobny, choć niejako odwrócony sposób także abstrakcyjne byty daja się materializować w obiektowej formie (to znaczy przedmiotu zmysłowego). Pojęciowe wyobrażenie pojedynku Achillesa z Hektorem można przecież sprowadzić do sensualnych rzeczy, gdy Homerowa

${ }^{9}$ S. Wróbel, Przedmowa do polskiego wydania, [w:] G. Harman, dz. cyt., s. XLVII.

${ }_{10}$ Zob. M. Glenn, Stipula Eturia 991, <www.marcuslink.com/pensofnote/stipula-eturia991.html> [dostęp: 14.04.215]. 
opowieść wydrukowana zostanie na kartach książkowego wydania Iliady albo wyświetlona na monitorze komputera.

Koncepcja przedmiotowego uobecniania się motywów antycznych nie tylko daje więc możliwość uchwycenia ich ponowoczesnej natury, lecz także stanowi zachętę do poszukiwania nowej metodologii badań nad obecnością greckiego i rzymskiego dziedzictwa we współczesnej kulturze. Wydaje się bowiem, że dotychczasowe sposoby jego postrzegania ograniczane były przez dominującą $\mathrm{w}$ dwudziestowiecznej myśli analizę doświadczenia percepcyjnego (vide fenomenologia) oraz filozofię analityczna, rozwijająca refleksję nad logicznymi i gramatycznymi strukturami języka. Na gruncie badań recepcyjnych nie stwarzało to inspiracji do porzucania tradycyjnej perspektywy metodologicznej, skupiającej się na rejestrowaniu obecności motywów antycznych, objaśnianiu ich znaczeń i podejmowaniu prób rozpoznawania funkcji - najczęściej literackich i ikonicznych ${ }^{11}$. Dopiero niedawno zaczą towarzyszyć temu głębszy namysł nad definiującym wpływem mediów na recypowane grecko-rzymskie treści, co wyniknęło głównie z uwzględnienia ich obecności także w kulturze popularnej ${ }^{12}$. Niestety nawet te - skądinąd nowatorskie - podejścia niewiele $\mathrm{w}$ istocie zmieniły, albowiem proponujący je badacze nigdy właściwie nie odeszli od pojmowania recepcji antycznych motywów jako przekazu znaczeń i idei, a nie ich uobecniania się jako rzeczy.

\section{Antyk (prze)projektowany}

Rysująca się obecnie możliwość zyskania nowego spojrzenia na grecko-rzymskie dziedzictwo Zachodu wymaga jednak swoistego przekucia filozoficznych kategorii realizmu spekulatywnego i harmanowskiego przedmiotu poczwórnego w instrumenty analityczne o praktycznej użyteczności. Wydaje się, że duże możliwości wypracowania takiego instrumentarium stwarza teoria metadesignu, w definiującym rozumieniu odnosząca się wszak do intencjonalnie kształtowanych rzeczy. Jej konceptualna przydatność w tym względzie

${ }^{11}$ Wśród wybitnych polskich badaczy stosujących te metodologie, z dawniejszych z pierwszym rzędzie należy wymienić T. Sinkę, autora dzieła Hellada i Roma w Polsce. Przeglad utworów na tematy klasyczne w literaturze polskiej ostatniego stulecia, Lwów 1933, z nowszych zaś przede wszystkim S. Stabryłę, spod którego pióra wyszły pomnikowe monografie: Hellada i Roma w Polsce Ludowej. Recepcja antyku w literaturze polskiej w latach 1945-1975, Kraków 1983 oraz Hellada i Roma. Recepcja antyku w literaturze polskiej w latach 1976-1990, Kraków 1996.

12 Zob. np. A.W. Mikołajczak, K. Dominas, M. Kaźmierczak, W cyfrowym labiryncie, Gniezno 2005; K. Dominas, Bogowie i herosi w kulturze popularnej na przykładzie produkcji Wolfganga Petersena „Troja” oraz Tarsema Singha „Immortales. Bogowie i herosi, [w:] Fantastyczność i cudowność. „Homo myticus”. Mityczne wzorce tożsamości, red. B. Trocha, G. Trębicki, H. Kubicka, Zielona Góra 2014, s. 73-87. 
wynika zarówno z natury samego przedmiotu badań, jak i z wypracowanych na gruncie metadesignu metod jego analizy i opisu. Teoria ta rozpatruje bowiem istotę designu w dwóch znaczeniowych perspektywach, z których jedna odnosi się do rzeczownikowego użycia tego pojęcia i koncentruje na wzornictwie, druga zaś związana jest z jego czasownikową formą i określa proces oraz praktykę projektowania. W pierwszym przypadku design można traktować jako przedmiotowe uobecnienie projektu, dające się opisać w kategoriach formy i funkcji, a także rzeczowych i pojęciowych aspektów jego ontologii. W drugim zaś, jak wyraził to Victor Papanek: „Procesem projektowym jest planowanie i kształtowanie przebiegu wykonywania dowolnej czynności z myśla o realizacji pożądanego, przewidywalnego celu"13. Oba te sposoby rozumienia designu prowadzą do wniosku, że jego kategoryzacje zasadniczo pokrywają się z biegunami przedmiotu poczwórnego Harmana, w związku z czym moga posłużyć do analizy i opisu ponowoczesnej recepcji antyku, pojmowanej jako swoiste przeprojektowanie grecko-rzymskich motywów w rzeczy.

W tym miejscu należy podkreślić, że to właśnie projektowalność przedmiotowo artykułowanych antycznych treści stanowi jedną z najważniejszych cech dystynktywnych ich nowej obecności się we współczesnym świecie. Oznacza to, że oczywistym odniesieniem procesu recepcji owych treści staje się dzisiaj pole dyskursywne metadesignu, w którego przestrzeni nie moga one być rozpatrywane inaczej, jak tylko w kategoriach intencjonalnych i projektowych. Dzieje się tak także dlatego, że: „Nie ma współcześnie obszaru, gdzie intuicyjnie rozumiany design - plan, projekt, zamiar intencja, planowanie, projektowanie - nie byłby istotnym czynnikiem w kształtowaniu ludzkiego doświadczenia"14. Jasno z tego wynika, że ponowoczesne „projektowanie" antyku w niewielkim stopniu dotyczy procesu wytwarzania znaczeń, lecz w przeważającej mierze odnosi się do kreowania modeli ludzkich z nim interakcji. Jest to zasadnicza przyczyna, dla której przeprojektowane w procesie recepcji greckie i rzymskie motywy-rzeczy należy traktować w kategoriach obiektywizacji relacji społecznych. Jak pisze bowiem Marek Krajewski w odniesieniu do wytworzonych przez człowieka dóbr, są one: „,...] uprzedmiotowionym ludzkim działaniem, stanami emocjonalnymi, odczuciami, myślami. Sa więc czymś, co, po pierwsze, zostało uzewnętrznione i co, po drugie, zostało zawarte w postaci materialnych lub niematerialnych wytworów"15.

${ }^{13}$ V. Papanek, Dizajn dla realnego świata. Środowisko człowieka i zmiana społeczna, przeł. J. Holzman, Łódź 2012, s. 23.

${ }^{14}$ M. Rosińska, Przemyśleć u/życie. Projektanci, przedmioty, życie społeczne, Warszawa 2010, s. 21.

${ }^{15}$ M. Krajewski, Wstęp, [w:] W stronę socjologii przedmiotów, red. M. Krajewski, Poznań 2005, s. 3. 
Płynie z tego zasadniczy wniosek, że istota ponowoczesnej recepcji antyku wcale nie jest przywoływanie, reinterpretowanie, transformowanie czy interpolowanie jego pierwotnych znaczeń, które na skutek przemian cywilizacyjnych w nowy sposób artykułowane są w literaturze (książkach, e-bookach i audiobookach), w filmach (kinowych i dostępnych cyfrowo), na stronach internetowych, portalach społecznościowych, w grach komputerowych, przedmiotach użytkowych, w usługach, turystyce czy reklamie i marketingu. Zupełnie nie na tym zasadza się nowość dzisiejszej recepcji i w żadnym razie zjawiska te nie mogą być uważane za istotę rewolucji, jaka dokonała się w zakresie obecności grecko-rzymskiego dziedzictwa w naszym świecie. To, co naprawdę zadecydowało o przeobrażeniu recepcyjnego paradygmatu, dokonało się bowiem na skutek cywilizacyjnego i kulturowego wciagnięcia antyku w kreatywne pole designu, pojmowanego jako intencjonalnie projektowanie i użytkowanie rzeczy.

Tak znacząca zmiana ontologii przedmiotu badań musi oczywiście wpływać na ocenę przydatności dopasowywanych doń metodologii, które w tradycyjnych ujęciach służyły głównie do semiotycznej i funkcjonalnej analizy znakowo kategoryzowanych motywów antycznych. Wydaje się, że właśnie $\mathrm{z}$ tego powodu traca one dzisiaj na znaczeniu - trudno bowiem oczekiwać, by metody wypracowane głównie na gruncie komparatystyki literackiej, a ostatnio także teorii nowych mediów, mogły się sprawdzać w odniesieniu do projektowo zorientowanych, urzeczowionych procesów recepcyjnych. Przedmiotowe uobecnianie się grecko-rzymskiego dziedzictwa nie tylko bowiem gruntownie zmieniło jego ontologię, lecz także przemodelowało mechanizmy kulturowej referencji i replikacji antyku w interakcji społecznej ${ }^{16}$.

\section{W stronę metadesignu}

W przeciwieństwie do dotychczasowych praktyk badawczych metateoria designu wyznacza więc odpowiedniejszą perspektywę poznawcza, podsuwając kategorie analityczne, które z jednej strony pozwalają uchwycić rzeczowość antycznych przedmiotów receptywnych, z drugiej zaś ukazać je jako wyraz relacji społecznych. Spośród opisowych kategoryzacji designu szczególnie przydatnymi instrumentami badań recepcyjnych wydają się określenia formy i funkcji oraz zmysłowego i pojęciowego aspektu przedmiotów. Dla zrozumienia ich znaczenia w projektowym uobecnianiu się greckich i rzymskich motywów należy odnieść je do dystynktywnych cech

${ }^{16}$ Pojęcia referencji i replikacji oraz ich funkcjonowanie w procesach cyfrowej recepcji antyku zostały omówione w: A.W. Mikołajczak, K. Dominas, M. Kaźmierczak, dz. cyt., s. 67-85. 
designu, określających jego właściwą naturę. Warto w tym miejscu przytoczyć wypowiedź Steve'a Jobsa pośrednio dotyczącą tego właśnie problemu:

Większość osób popełnia błąd, uważając, że design ogranicza się do tego, jak coś wygląda. Ludzie sądza, że to tylko zewnętrzne wykończenie; że projektant dostaje pudełko i polecenie: „Zrób tak, żeby to ładnie wyglądało!”. Naszym zdaniem wzornictwo wcale nie na tym polega. Nie chodzi o to, jak coś wygląda i jakie wzbudza uczucia. Wzornictwo określa, jak dany przedmiot działa ${ }^{17}$.

Innymi słowy, design wskazuje, do czego określona rzecz służy, a także podpowiada sposób, w jaki należy jej używać. Zdefiniowane w projekcie działanie danej rzeczy określa zatem charakter interakcji między przedmiotem a użytkownikiem, zaś w szerszej perspektywie zapośrednicza także relacje społeczne, obiektywizując je w zaprojektowanych rzeczach, którymi posługują się zwykle ludzkie zbiorowości.

Te właściwości projektowania wynikaja z natury naszej świadomości, która według Franca Brentano ${ }^{18}$ zawsze jest świadoma czegoś, na czymś się koncentruje, ku czemuś zmierza - czyli ma w swojej istotowości konkretny, wyodrębnialny potencjał intencjonalności. Jeśli jest on więc ukierunkowany ku jakiemuś celowi, nastawiony na jego osiagnięcie, to - jak uważa Bartłomiej Sipiński - utożsamia się z nim, rzeczowo uobecnia w jego istocie, stając się ,przedmiotem intencjonalnym” ${ }^{19}$. Rzuca to nowe światło na spekulatywny realizm Harmana, w szczególności zaś na wzajemne dopełnianie się rzeczywistych i zmysłowych aspektów rzeczy, które w perspektywie metadesignu mogą być postrzegane zarówno w wymiarze przedmiotowym, jak i podmiotowym. Wszelkie bowiem zaprojektowane przez człowieka rzeczy można uznać za byty intencjonalne, a więc powstałe z określonym zamiarem i dla określonego celu - z czego należy wnioskować, że w swej przedmiotowości zawieraja one intencje celowości, które podmiotowo uobecnione są w ludzkiej świadomości. Związek między nimi, mający charakter Kartezjańskiego cogitatio $^{20}$, niweluje więc nie tylko przepaść między przedmiotowością i podmiotowością ${ }^{21}$, zapośrednicza relacje między aspektem rzeczywistym i zmysłowym Harmanowskiego przedmiotu poczwórnego.

Dla dociekań nad recepcja antyku w kulturze ponowoczesnej ma to zasadnicze znaczenie, albowiem pozwala zmysłowe aspekty przedmiotu

${ }^{17}$ Za: L. Kahney, Jony Ive. Geniusz, który zaprojektowat najstynniejsze produkty Apple, przeł. M. Jóźwiak, Kraków 2014, s. 147.

${ }^{18}$ F. Brentano, Psychologia z empirycznego punktu widzenia, przeł. W. Galewicz, Warszawa 1999, s. 143 inn.

${ }^{19}$ B. Sipiński, Dialog, Poznań 2015, s. 213-218.

${ }^{20}$ E. Husserl, Idee czystej fenomenologii i fenomenologicznej filozofii, przeł. D. Gierulanka, Warszawa 1967, s. 58-61.

${ }^{21}$ B. Sipiński, Odkrywajac podmiotowość z Lévinasem i Marionem, Poznań 2013, s. 232-241. 
poczwórnego utożsamiać z przedmiotowa, czyli rzeczowo uobecnianą formą grecko-rzymskich treści, podczas gdy jego aspekty rzeczywiste można traktować jako podmiotowa, czyli spekulatywna reprezentację ich formy.

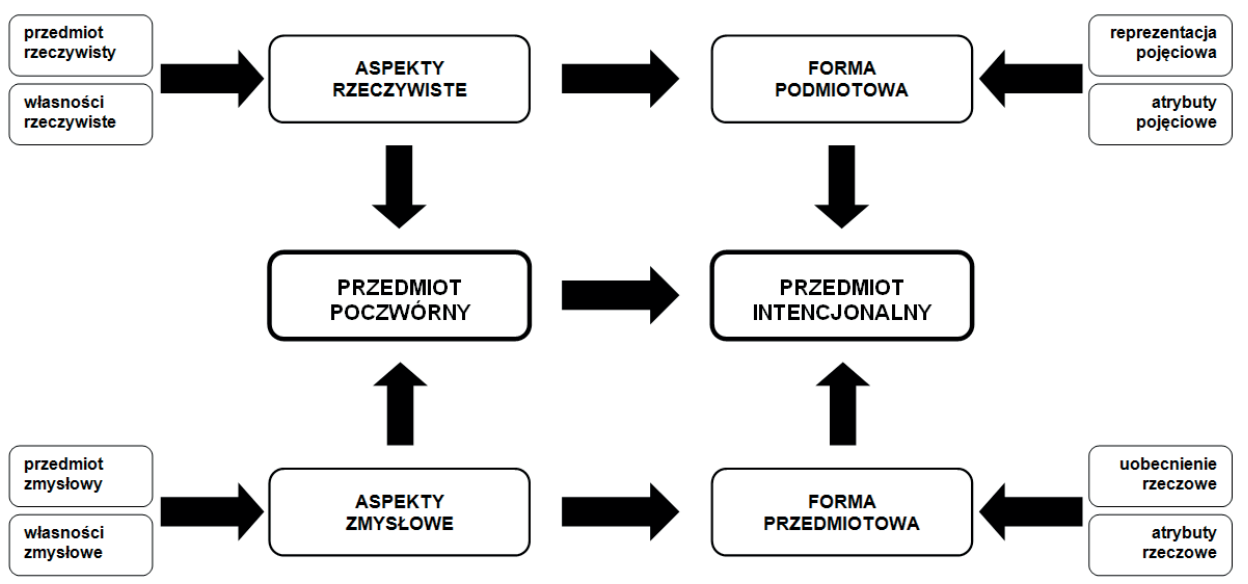

Ryc. 1. Translacja kategorialna przedmiotu poczwórnego

Proponowane ujęcie otwiera zupełnie nowe możliwości analizowania i opisu antycznych przedmiotów receptywnych, które w tej perspektywie ujawniają ukryte, relacyjne wymiary swojej przedmiotowej podmiotowości. Pozwala to postrzegać je jako obiekty dwubiegunowe - zakorzenione tyleż w świecie zewnętrznym, ile spekulatywnie obecne także w ludzkiej świadomości. Warto w tym miejscu ponownie przywołać koncepcję Bartłomieja Sipińskiego, z której można wywnioskować, że ów związek między obiema reprezentacjami przedmiotu intencjonalnego tworzy rodzaj „splotu intencjonalnego"22. Stanowi on iunctum ich jedności i tożsamości, pomimo że istnieją one rozdzielnie - „tu” i „tam”, w podmiotowej i przedmiotowej formie. Odnoszac to rozumienie do antycznych przedmiotów receptywnych, można więc przyjąć, że to właśnie splot intencjonalny aktualizuje ich użytkową potencjalność - stąd proces ten powinno się nazwać „recepcją intencjonalno-funkcjonalną”.

\section{Recepcja intencjonalno-funkcjonalna}

Chcąc dokładniej przyjrzeć się mechanizmowi tej zmiany, trzeba przywołać kolejna, obok formy, kategorię z zakresu metadesignu - czyli pojęcie funkcji przedmiotu. Wymaga to wszelako kilku wyjaśnień, albowiem kate-

${ }^{22}$ B. Sipiński, Dialog..., s. 213 i nn. 
goria ta (najczęściej kojarzona właśnie z forma) rozmaicie była w przeszłości rozumiana, a w związku z tym brakuje jej wyrazistej jednoznaczności. Dyskusję na tym pojęciem (w odniesieniu do architektury) zapoczątkował już Witruwiusz, wymieniając w swym traktacie De architectura libri decem trzy ściśle ze sobą związane cechy, mianowicie: trwałość, użyteczność i piękno (łac. firmitas, utilitas, venustas). Dla późniejszych funkcjonalistów oznaczało to, że piękno jest naturalną konsekwencją konstrukcji i funkcjonalności budynku, czemu dał wyraz jeden z najbardziej wpływowych neogotyckich architektów Augustus Welby Northmore Pugin, pisząc, że „należy uwzględniać jedynie to, co jest istotne ze względu na wygodę, konstrukcję lub właściwości” ${ }^{23}$. Podchwycił to potem Luis Sullivan, autor słynnej maksymy „forma (zawsze) wynika z funkcji” [ang. form (ever) follows function], który miał jednak inne niż Pugin zdanie na temat zaliczania ornamentyki do funkcjonalnych właściwości architektury, co w rezultacie doprowadziło $\mathrm{w}$ dyskursie do postawienia pytań: o jakie w istocie, a przede wszystkim czyje funkcje chodzi ${ }^{24}$ ? Odpowiedzi na te pytania są wciąż kluczowe także dla naszych rozważań nad funkcjonalnością antycznych przedmiotów receptywnych w procesie ich intencjonalnej interakcji z użytkownikami.

Twierdząc zatem, że intencjonalność determinuje cele, do jakich rzeczy zostały zaprojektowane, a przez to określa także sposób ich działania, należy założyć, że jest ona również wpisana w funkcjonalność przedmiotów recypowanych, uczestniczących w procesie uobecniania się antyku. Oznacza to, że ponowoczesne społeczeństwo wykorzystuje go do wyrażania swoich emocjonalnych i kulturowych wartości, które są niejako „wprojektowywane” w recypowane obiekty. Jest to wszakże tylko jedna ze stron tego medalu, albowiem ta sama intencjonalność, upostaciowiona w antycznych przedmiotach receptywnych, sama także kształtuje i transformuje owe wartości. Dzieje się tak, gdy są one każdorazowo aktualizowane w konkretnych interakcjach z ludzkimi użytkownikami tego dziedzictwa. Nowa funkcjonalność antyku ma więc charakter projektowy i zarazem utylitarny, albowiem jest on $\mathrm{w}$ procesie recepcji zarówno intencjonalnie uprzedmiotowiany, jak i celowo zużytkowywany - rzec można pod dyktando wewnętrznej intencjonalności samych przedmiotów. Prowadzi to do stwierdzenia, że za istotę współczesnej recepcji antyku uznać można ten rodzaj kreatywności, jaki przypisuje się współczesnemu designowi, o którym Deyan Sudjic powiada, że:

[...] we wszystkich swych przejawach jest on DNA społeczeństwa przemysłowego albo postprzemysłowego, jeśli w takim dziś żyjemy. To kod, który powinniśmy

${ }^{23}$ Za: R. Weston, 100 idei, które zmienity architekturę, przeł. E. Tomczyk, Raszyn 2011, s. 120 .

${ }^{24}$ Tamże, s. 120. 
zgłębić, jeśli chcemy mieć szansę zrozumienia współczesnego świata. Dizajn jest wytworem naszego systemu gospodarczego. Nosi na sobie piętno technologii, z która musimy sobie radzić ${ }^{25}$.

Zatem to społeczny i cywilizacyjny kontekst powoduje, że w polu napięć splotu intencjonalnego sprawczość antycznych przedmiotów receptywnych znajduje się nie tylko po ludzkiej stronie - dysponują nią także same przedmioty. Wynika stąd, że sprawczość ta nie może być odnoszona wyłącznie do podmiotowej funkcji intencjonalności obecnej w naszych umysłach, lecz należy ją dostrzegać także w funkcji przedmiotowej, uobecnionej w receptywnych rzeczach. Związek ten obrazuje translacja kategorii formalnych właściwych przedmiotowi intencjonalnemu, przenosząca je na kategorie opisowe przedmiotu funkcjonalnego.

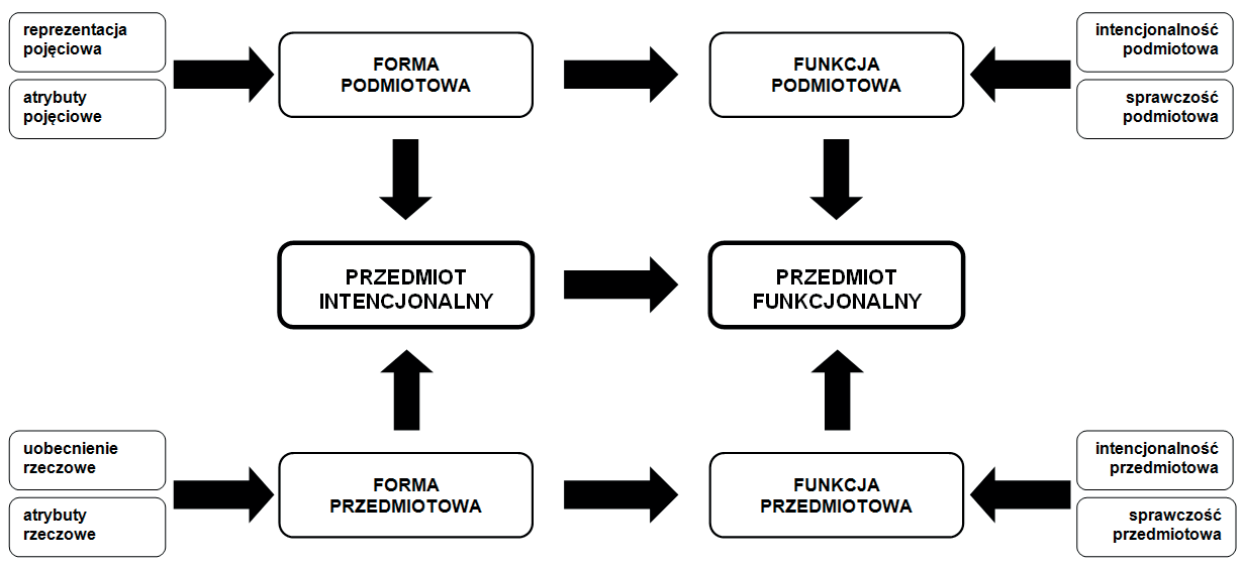

Ryc. 2. Translacja kategorialna przedmiotu intencjonalnego

Dochodzimy w tym miejscu do istoty receptywnej funkcjonalności antyku, która warunkowana jest zjawiskiem dopełniania się podmiotowej i przedmiotowej intencjonalności recypowanych przedmiotów. Specyfika ta powoduje, że funkcji recepcyjnych nie sposób rozpatrywać z jednego tylko punktu widzenia, ograniczonego do ludzkiej sprawczości, ignorując autonomiczną sprawczość samych przedmiotów. Prowadzi to do dezaktualizacji tradycyjnych pytań stawianych dotąd w dociekaniach nad recepcja, a odnoszących się do rozumienia znaczeń motywów antycznych, badania roli, jaka pełnia one w strukturze tekstu, czy analizowania wpływu mediów będących ich nośnikami. Wszystkie te kwestie zasadzają się bowiem na jednostronnym widzeniu ontologii antycznych przedmiotów receptywnych jako

${ }^{25}$ D. Sudjic, dz. cyt., s. 55. 
bytów zależnych, pozbawionych własnej podmiotowości, których sprawczość znajduje się całkowicie po stronie naszej intencjonalności. Jest to główny powód, dla którego były one dotychczas postrzegane wyłącznie przez pryzmat ludzkiej percepcji i naszej zdolności pojmowania sensów. Takie antropocentryczne podejście nie pozwalało ujmować procesów recepcyjnych jako rodzaju widowisk ${ }^{26} \mathrm{z}$ udziałem ludzkich i nie-ludzkich uczestników. Tymczasem takim właśnie spektaklem wydaje się być współczesna recepcja antyku, postrzegana jako swoista gra aktorów z rekwizytami - równorzędnie i pospołu kreujaccych (jak opisuje to Actor Network Teory - ANT) ${ }^{27}$ postacie „aktantów”, pojmowanych w kategoriach przedmiotów o zintegrowanej, podmiotowo-przedmiotowej sprawczości.

\section{W stronę ANT}

Akceptacja teorii aktora-sieci jako adekwatnego sposobu opisu i analizy procesu recepcji antyku jest więc konsekwencją przyjętej na wstępie tezy o rzeczowo-przedmiotowym sposobie funkcjonowania grecko-rzymskiego dziedzictwa w ponowoczesnej cywilizacji. Wpisuje się ona w pogląd Bjørna Olsena, że jedną z przyczyn ukształtowania się metodologii ANT była właśnie chęć ustosunkowania się do:

[...] błędów popełnianych przez nadmierne uspołecznienie koncepcji człowieka i społeczeństwa. Technika, rzeczy, nauka i natura nie są czymś „dodatkowym” wobec społeczeństwa, nie stanowią składników zewnętrznej rzeczywistości, które wywołuja jakieś wydarzenia w zupełnie czystym społecznym środowisku [...]. Społeczeństwo stanowi raczej skomplikowaną tkankę intymnych odniesień łączących i kojarzacych ludzi i rzeczy, czyli kolektyw, w którym ludzie i nie-ludzie wspólnie żyją i pracują ${ }^{28}$.

Stwierdzenie to, w kontekście intencjonalno-funkcjonalnego rozumienia recepcji antyku, łatwo odnieść do konceptu aktanta w teorii aktora-sieci. Ze słów Olsena wynika bowiem, że interakcji ludzi z antycznymi przedmiotami receptywnymi nie powinno się traktować w kategoriach opozycyjnych i dualistycznych, ale określać poprzez relacje, współdziałanie i wzajemne dopełnianie się ich podmiotowości. Właśnie te relacyjne układy ludzkich i nie-ludzkich partnerów, tworzące sieci wzajemnych współzależności, stanowią obecnie główna przestrzeń recepcji grecko-rzymskiego dziedzictwa,

${ }^{26}$ Pojęcie to w odniesieniu do designu zaproponowali Walker i Chaplin, zob. J. Attfield, Wild Things: The Material Culture of Everyday Life, New York 2000, s. 28.

${ }^{27}$ Zob. B. Latour, Splatajac na nowo to, co społeczne. Wprowadzenie do teorii aktora-sieci, tłum. K. Abriszewski, A. Derra, Kraków 2010.

${ }^{28}$ B. Olsen, W obronie rzeczy. Archeologia i ontologia przedmiotów, przeł. B. Shallcross, Warszawa 2013, s. 213-214. 
uobecniającego się w hybrydycznej ontologii aktantów. Ich zdolność do działania czyni z nich mediatorów w relacjach społecznych, obiektywizując je i nadając im funkcjonalny charakter. Oznacza to, że relacje te zyskuja w aktantach status rzeczy, kształtowanych z jednej strony przez ludzka, z drugiej przez przedmiotową intencjonalność. Uobecnione w nich antyczne treści są więc aktualizowane zarówno przez nasza, jak i przedmiotową sprawczość, co powoduje, że odbywa się to nie tylko wedle ludzkich zamysłów, lecz także zgodnie z właściwościami i przeznaczeniem rzeczy. Odwołując się do koncepcji afordancji (ang. affordance) Gibsona, można zatem powiedzieć, że dostarczają one gotowości do działania w prosty, niezapośredniczony sposób $^{29}$. Książka umożliwia poznanie treści Iliady, samolot - znalezienie się w rzymskim Koloseum, komputer - obejrzenie filmu Gladiator Ridleya Scotta. Jak stwierdza bowiem Bjørn Olsen, komentując koncepcję Gibsona:

Rzeczy, materiały, istnienia dostarczają nam bogactwa afordancji, które pomagaja naszej codziennej aktywności, zezwalają na nia, kierują nia, zapobiegają jej i w inny sposób wpływają na nią. Trwałość i uporczywość rzeczy [...] mogą być interpretowane jako wspólna afordancja, która dzięki szerokiemu wachlarzowi indywidualnych istnień ułatwia pewne czyny, postawy i znaczenia ${ }^{30}$.

Innymi słowy, rzeczy umożliwiają realizację prozaicznych zadań, do których zostały stworzone, ale mogą także służyć innym, bardziej wysublimowanym działaniom i celom, takim właśnie, jakim jest recepcja antyku. Strony www, sale uniwersyteckie, filmy, miasto Rzym czy pióro Aurora pozwalają ludziom nie tylko surfować w Internecie, słuchać wykładów, zwiedzać zabytki i pisać, lecz także dzięki nim obcować z grecko-rzymskim dziedzictwem Europy, co aktualizuje i podtrzymuje relacje społeczne w zakresie poczucia przynależności do cywilizacyjnej wspólnoty Zachodu. Choć może się wydawać, że poczucie to w ogromnej mierze kształtuja same antyczne idee i wartości, to przecież nie oddziałują one wprost, abstrakcyjnie nie przenikają do ludzkich umysłów, lecz uświadamiamy je sobie za pośrednictwem używanych przez nas przedmiotów: i-pada, na którym czytam $D e$ republica Cycerona, gry RPG Hegemony Rome: Rise of Caesar ${ }^{31}$, budynku teatru, gdzie wystawiana jest Antygona Sofoklesa, zapalniczki w kształcie doryckiej kolumny, którą zapalam fajkę itp. Dzięki tym codziennym pośrednikom, skromnym sługom powszedniości, antyczne idee i wzorce stają się dla nas namacalnie dostępne, poddając się zmysłowemu poznaniu i zarazem spekulatywnym osądom.

${ }^{29}$ J. Gibson, The Ecological Approach to Visual Perception, Hillsdale 1986, s. 127 i nast.

${ }^{30}$ B. Olsen, dz. cyt., s. 227.

${ }^{31}$ Hegemony Rome: Rise of Caesars, Longbow Digital Arts, 2014, <www.longbowgames. com/rome/> [dostęp: 16.04.2015]. 
Należy jednak pamiętać, że recypowane w ten sposób treści-rzeczy nie są wytworami jedynie ludzkiej intencjonalności - na ich przekaz wpływają wszak istnienie i funkcje uobecniajacych je przedmiotów. Ich działalność determinuje nie tylko czysto utylitarne afordancje, lecz sprawia, że spełniają one - jak podkreśla Olsen: „[...] o wiele istotniejszą rolę. Ta generująca i konstytutywna rola polega na czymś znacznie ważniejszym niż służenie jako umotywowane znaki lub materialne metafory - rzeczy mają rzeczywiste własności, których dostarczają społecznym konstruktom i społecznej przedsiębiorczości" ${ }^{2}$. Przykładowo, bilety wstępu na Akropol limitują dostęp do Partenonu, dzieląc przestrzeń na obszar zamknięty i otwarty, co w relacji z grodzacym wzgórze płotem wyznacza granice, które - nieistotne czy w sposób zamierzony, czy nie - ogromnie wpływają na poznawalność tej budowli, jej emocjonalny odbiór, a także na poczucie osobistego z nią związku. Podobnie Caesars Palace - hotel i kasyno w Las Vegas przyciaga klientów nie tylko nadzieją wygranej w ruletkę, lecz także obietnicą luksusu i wyjątkowego traktowania w miejscu, gdzie poczują się jak prawdziwi cezarowie $^{33}$. W ten sposób zarabiając pieniądze, kasyno równocześnie aktualizuje i utrwala w świadomości społecznej mit starożytnego Rzymu, jako uosobienia wiecznej potęgi, bogactwa i władzy.

\section{Antyk w sieci}

Przytoczone przykłady, obrazujac współczesne mechanizmy recepcji greckiego i rzymskiego dziedzictwa, skłaniają do stwierdzenia, że przedmiotowe afordancje służące (przy okazji) uobecnianiu i dystrybucji antycznych treści, w oczywisty sposób wikłaja je w różnorakie relacje i odniesienia, właściwe sieciowemu charakterowi aktantów. Wynika to z demokratycznej natury przedmiotów, których utylitarne funkcje realizowane są w otwartej wspólnocie użytkowników, a nie w waskich zbiorowościach wyodrębnianych specjalnie dla celów recepcji. W interakcjach ludzkich aktorów z antycznymi rekwizytami daje to nieograniczoną możliwość tworzenia ich różnorodnych konfiguracji i multiplikujących się relacji, co prowadzi dziś do sieciowego uspołecznienia procesów recepcyjnych. W rezultacie ponowoczesnej recepcji antyku nie można dalej traktować jako odosobnionych ludzkich działań, podejmowanych w celu aktualizacji grecko-rzymskiej tradycji, bez uwzględniania sieci społecznych odniesień i bez udziału w tym procesie nie-ludzkich

${ }^{32}$ B. Olsen, dz. cyt., s. 226.

${ }^{33}$ Zob. oficjalna strona Caesars Palace Las Vegas Hotel and Casino, <www.caesars. com> [dostęp: 16.04.2015]. 
współuczestników. Jak zauważa bowiem Latour: „Działanie nie jest [...] własnością człowieka, lecz stowarzyszenia aktantów”34.

Pogląd, że ludzka podmiotowość pozbawiona jest przywileju sprawczej wyłączności w procesie recepcji antyku, wypływa z ogólniejszych założeń dotyczacych jej ograniczonej suwerenności w interakcjach z przedmiotami. Można to odnieść do koncepcji „cząstkowej osobowości” Roya Wagnera ${ }^{35}$ oraz do pojęcia osób „częściowalnych” (partible) Marilyn Starthern ${ }^{36}$. Autorzy ci zwrócili uwagę na swoiste rozpraszanie się atrybutów ludzkiej podmiotowości, która w podejmowanych działaniach zostaje rozdystrybuowana pomiędzy rozmaite wykorzystywane w ich toku przedmioty. Będąc współsprawcami naszych wysiłków, zawieraja one w sobie cząstki nas samych - naszych intencjonalności i osobowości. Istnieją one w rzeczach i współdziałają z ich własnymi funkcjonalnościami, czyli tak naprawdę to my sami istniejemy w ten właśnie sposób - poza soba, w naszej rozczłonkowanej, rozproszonej tożsamości. Dlaczego więc tylko ludzka podmiotowość wciąż wydaje się nam głównym, jeśli nie jedynym podmiotem sprawczym sieciowych procesów recepcyjnych? Wyjaśnienie tego paradoksu podaje Bjørnal Olsen, w swym komentarzu do teorii aktora-sieci Latoure'a:

[...] gdy sieci ulegaja stabilizacji - innymi słowy, gdy ich rzeczowe składniki stają się masowe i nieodzowne - ważne elementy ich funkcjonowania chowają się ( nej skrzynce") i uwaga zostaje skierowana ku jednemu lub kilku aktorom, którzy otrzymują wszystkie zaszczyty i rozgłos za pracę wykonaną przez tych pocacych się przy taśmie ${ }^{37}$.

Jest to $\mathrm{w}$ istocie opis procesu ponowoczesnej recepcji antyku, którego sieciowa łączliwość stabilizuje rozmaite pola gry, zdominowane przez aktorów-celebrytów o największej rozpoznawalności - choć niekoniecznie sprawczej funkcjonalności. Podobny mechanizm recepcji, odniesiony do recepcji mitu w literaturze popularnej i w nowych mediach, przedstawił ostatnio Konrad Dominas ${ }^{38}$, nie wykorzystując wszelako do jego analizy koncepcji aktora-sieci. Prezentowane przez niego podejście opiera się na wyróżnieniu trzech receptywnych obszarów sieci: literatury antycznej, literatury popularnej oraz nowych mediów. W każdej z tych przestrzeni działaja odrębne mechanizmy formowania się literackiego, popularnego i medialnego kanonu mitu (które my chętnie powiązalibyśmy z afordancja-

${ }^{34}$ Za: B. Olsen, dz. cyt., s. 229.

${ }^{35}$ Zob. R. Wagner, The fractal person, [w:] Big Man and Great Man: Personifications of Power in Melanesia, eds. M. Godelier, M. Strathern, Cambridge 1991.

${ }^{36}$ Zob. M. Strathern, The Gender of the Gift: Problems with Women and Problems with Society in Melanesia, Berkeley 1988.

${ }^{37}$ B. Olsen, dz. cyt., s. 222.

${ }^{38}$ M. Czeremski, K. Dominas, M. Napiórkowski, Mit pod lupq II, Kraków 2013, s. 48-78. 
mi aktantów). Koncepcja Dominasa, chociaż zakorzeniona wciąż w semiotyczno-medialnym rozumieniu recepcji, przełamuje już antropocentryczne postrzeganie tego procesu, zwracając uwagę na rolę, jaką odgrywa w nim sprawczość samej sieci.

$$
* * *
$$

Reasumując, można stwierdzić, że nowa, bardziej urzeczowiona metodologia badań nad recepcja antyku mogłaby rozjaśnić wiele kwestii, które domagają się szerszego spojrzenia, integrującego je na płaszczyźnie ontologicznej i epistemologicznej. Chodzi zwłaszcza o możliwość ogarnięcia interpretującym oglądem nie tylko znakowych, lecz także rzeczowych funkcji dziedzictwa antycznego, co pozwoliłoby rozpoznać mechanizmy jego użytkowania w procesach nie tylko kulturowych, lecz także cywilizacyjnych. Inspiracją do dokonania takiego zwrotu w refleksji nad recepcją wydają się koncepcje wypracowane na gruncie nowej humanistyki.

Jedną z propozycji wywodzących się z tego nurtu jest postulat porzucenia analizy bytów (konkretnych i abstrakcyjnych) w perspektywie tekstualnej i narracyjnej na rzecz refleksji nad relacjami łączącymi je z ludźmi, czyli nad ich rzeczową użytkowością. Podejście to w stosunku do tradycji antycznej może wydawać się radykalne, gdy jednak rozpatrzyć je z punktu widzenia realizmu spekulatywnego w ujęciu Grahama Harmana, wypada uznać je za uzasadnione i celowe. Cóż bowiem stoi na przeszkodzie, by grecko-rzymskiego dziedzictwa cywilizacyjnego nie potraktować jako zbioru pojęciowych i materialnych obiektów podlegających recepcji? Chociaż każdy z nich ma wiele różnych atrybutywnych własności i akcydentalnych właściwości, to przecież stanowią one wyodrębnianąi uchwytną zarówno pojęciowo, jak i zmysłowo całość. Dotyczy to więc nie tylko rzeczy materialnych, lecz także przedmiotów semiotycznych, takich jak inwokacja do Odysei czy akt zabicia Minotaura.

Wszystkie te obiekty stanowia zatem rodzaj antycznej pramacierzy, z której w procesie recepcji wydobywają je użytkownicy, zadzierzgując z nimi w ten sposób relacyjne więzi o symbolicznym i emotywnym nacechowaniu. Ostatecznie tworzą one złożone sieci interakcji, w których urzeczowione antyczne treści podlegają twórczej transformacji w obiekty zaspakajające potrzeby nowej użytkowości. Ujęcie takie bliskie jest teorii aktora-sieci (ANT), na gruncie której antyczne obiekty wraz z zespolonymi z nimi użytkownikami traktować można jako aktanty. Jeśli bowiem wszystkie recypowane grecko-rzymskie treści są rzeczami, to mają one także przedmiotowe afordancje umożliwiające korzystanie zarówno z ich funkcji rzeczowych jak i semantycznych. W ten sposób akwizycję antyku 
rozumieć można jako proces użytkowania dziedzictwa klasycznego w jego ontologicznych i semantycznych upostaciowieniach. Jeśli połączyć ze sobą oba te spojrzenia, to razem wyznaczaja one nowa perspektywę dla badań recepcyjnych.

\section{BIBLIOGRAFIA}

Antiquity in Popular Literature and Culture, <www.phsi.amu.edu.pl/fancud_konferencja. html> [dostęp: 14.04.2015].

Attfield J., Wild Things: The Material Culture of Everyday Life, New York 2000.

Best Films about Ancient and Medieval Times, <www.imdb.com/list/ls008306192/> [dostęp: 16.04.2015].

Brentano F., Psychologia z empirycznego punktu widzenia, przeł. W. Galewicz, Warszawa 1999.

Caesars Palace Las Vegas Hotel and Casino, <www.caesars.com> [dostęp: 16.04.2015].

Czeremski M., Dominas K., Napiórkowski M., Mit pod lupq II, Kraków 2013, s. 48-78. Dominas K., Bogowie i herosi w kulturze popularnej na przykładzie produkcji Wolfganga Petersena „Troja” oraz Tarsema Singha „Immortales. Bogowie i herosi”, [w:] Fantastyczność i cudowność. „Homo myticus”. Mityczne wzorce tożsamości, red. B. Trocha, G. Trębicki, H. Kubicka, Zielona Góra 2014.

Dominas K., Internetowa recepcja mitu na przyktadzie wybranych podań grecko-rzymskiej literatury, [w:] Studia mitoznawcze. Wspótczesna obecność mitu, red. I. Błocian, E. Kwiatkowska, Torun 2012.

Gibson J., The Ecological Approach to Visual Perception, Hillsdale 1986.

Glenn M., Stipula Eturia 991, <www.marcuslink.com/pensofnote/stipula-eturia991. html> [dostęp: 14.04.215].

Harman G., Traktat o przedmiotach, przekł. i posłowie M. Rychter, Warszawa 2013.

Hegemony Rome: Rise of Caesars, Longbow Digital Arts, 2014, <www.longbowgames. com/rome/> [dostęp: 16.04.2015].

Huntington S.P., Zderzenie cywilizacji i nowy kształt ładu światowego, przeł. H. Jankowska, Warszawa 1997.

Husserl E., Idee czystej fenomenologii i fenomenologicznej filozofii, przeł. D. Gierulanka, Warszawa 1967.

Kahney L., Jony Ive. Geniusz, który zaprojektowat najstynniejsze produkty Apple, przeł. M. Jóźwiak, Kraków 2014.

Krajewski M. (red.) W stronę socjologii przedmiotów, Poznań 2005.

Latour B., Splatajac na nowo to, co społeczne. Wprowadzenie do teorii aktora-sieci, tłum. K. Abriszewski, A. Derra, Kraków 2010.

Mikołajczak A., Dominas K., Kaźmierczak M., W cyfrowym labiryncie, Gniezno 2005.

Olsen B., W obronie rzeczy. Archeologia i ontologia przedmiotów, Warszawa 2013.

Papanek V., Dizajn dla realnego świata. Środowisko człowieka i zmiana społeczna, przeł. J. Holzman, Łódź 2012.

Perseus Digital Library, <www.perseus.tufts.edu> [dostęp: 14.04.2015]. 
Rosińska M., Przemyśleć u/życie. Projektanci, przedmioty, życie społeczne, Warszawa 2010.

Sinko T., Hellada i Roma w Polsce. Przeglad utworów na tematy klasyczne w literaturze polskiej ostatniego stulecia, Lwów 1933.

Sipiński B., Dialog, Poznań 2015.

Sipiński B., Odkrywajac podmiotowość z Lévinasem i Marionem, Poznań 2013.

Stabryła S., Hellada i Roma. Recepcja antyku w literaturze polskiej w latach 1976-1990, Kraków 1996.

Stabryła S., Hellada i Roma w Polsce Ludowej. Recepcja antyku w literaturze polskiej w latach 1945-1975, Kraków 1983.

Strathern M., The Gender of the Gift: Problems with Women and Problems with Society in Melanesia, Berkeley 1988.

Sudjic D., Język rzeczy. Dizajn i luksus, moda i sztuka. W jaki sposób przedmioty nas uwodza, przeł. A. Puchejda, Kraków 2013.

Wagner R., The fractal person, [w:] Big Man and Great Man: Personifications of Power in Melanesia, eds. M. Godelier, M. Strathern, Cambridge 1991.

Weston R., 100 idei, które zmienity architekture, przeł. E. Tomczyk, Raszyn 2011.

Wróbel S., Przedmowa do polskiego wydania, [w:] G. Harman, Traktat o przedmiotach, przekł. i posłowie M. Rychter, Warszawa 2013. 
